\title{
Confucianism and Folklore in Vietnamese Fantasy Short Stories: The Case of Ghost Stories
}

\author{
Nguyen Thi Kim Ngan \\ HU_University of Education
}

Follow this and additional works at: https://docs.lib.purdue.edu/clcweb

Part of the Classical Literature and Philology Commons, Other Religion Commons, and the South and Southeast Asian Languages and Societies Commons

Dedicated to the dissemination of scholarly and professional information, Purdue University Press selects, develops, and distributes quality resources in several key subject areas for which its parent university is famous, including business, technology, health, veterinary medicine, and other selected disciplines in the humanities and sciences.

CLCWeb: Comparative Literature and Culture, the peer-reviewed, full-text, and open-access learned journal in the humanities and social sciences, publishes new scholarship following tenets of the discipline of comparative literature and the field of cultural studies designated as "comparative cultural studies." Publications in the journal are indexed in the Annual Bibliography of English Language and Literature (Chadwyck-Healey), the Arts and Humanities Citation Index (Thomson Reuters ISI), the Humanities Index (Wilson), Humanities International Complete (EBSCO), the International Bibliography of the Modern Language Association of America, and Scopus (Elsevier). The journal is affiliated with the Purdue University Press monograph series of Books in Comparative Cultural Studies. Contact: <clcweb@purdue.edu>

\section{Recommended Citation}

Ngan, Nguyen Thi Kim. "Confucianism and Folklore in Vietnamese Fantasy Short Stories: The Case of Ghost Stories ." CLCWeb: Comparative Literature and Culture 23.4 (2021): <https://doi.org/10.7771/1481-4374.3455>

This text has been double-blind peer reviewed by $2+1$ experts in the field.

The above text, published by Purdue University Press @P Purdue University, has been downloaded 0 times as of 02/10/ 22.

This document has been made available through Purdue e-Pubs, a service of the Purdue University Libraries. Please contact epubs@purdue.edu for additional information.

This is an Open Access journal. This means that it uses a funding model that does not charge readers or their institutions for access. Readers may freely read, download, copy, distribute, print, search, or link to the full texts of articles. This journal is covered under the CC BY-NC-ND license. 


\section{PURDUE}

U N I V E R S I T Y UNIVERSITY PRESS < http://www.thepress.purdue.edu>

\section{CLCWeb: Comparative Literature and Culture}

ISSN 1481-4374 <http://docs.lib.purdue.edu/clcweb> Purdue University Press @Purdue University

CLCWeb: Comparative Literature and Culture, the peer-reviewed, full-text, and open-access learned journal in the humanities and social sciences, publishes new scholarship following tenets of the discipline of comparative literature and the field of cultural studies designated as "comparative cultural studies." In addition to the publication of articles, the journal publishes review articles of scholarly books and publishes research material in its Library Series. Publications in the journal are indexed in the Annual Bibliography of English Language and Literature (ChadwyckHealey), the Arts and Humanities Citation Index (Thomson Reuters ISI), the Humanities Index (Wilson), Humanities International Complete (EBSCO), the International Bibliography of the Modern Language Association of Ámerica, and Scopus (Elsevier). The journal is affiliated with the Purdue University Press monograph series of Books in Comparative Cultural Studies. Contact: <clcweb@purdue.edu>

\section{Volume 23 Issue 4 (December 2021) Article 1 Nguyen Thi Kim Ngan,}

"Confucianism and Folklore in Vietnamese Fantasy Short Stories: The Case of Ghost Stories" <http://docs.lib.purdue.edu/clcweb/vol23/iss4/1>

Contents of CLCWeb: Comparative Literature and Culture 23.4 (2021)

<http://docs.lib.purdue.edu/clcweb/vol23/iss4/>

Abstract: Truyền $k \grave{y}$, which is a genre of fantasy short stories, was formed and developed in the historic period of medieval literature of Vietnam in the sixteenth and seventeenth centuries. Despite being derived from a similar Chinese genre, the truyền ky of Vietnam was the work of the endogenous development of the national fantasy short story, which was closely associated with folk literature and historical prose. However, at the time of its inception, as well as at the glorious top of this genre, truyên $k y$ had never been accepted as an official genre. It was rather a metaphor for unorthodox discourse in formal Confucian society. The reason is that truyền $k \dot{y}$ founded the first elements of folk narrative genres that were considered inferior and which Confucius advised Confucians to reject. Therefore, truyên $k \dot{y}$ deeply influenced Confucian doctrines, yet in this genre by itself, the deficiencies of Confucian philosophy related to the metaphysical world were exposed in competition with other non Confucian religions that had emerged, such as Buddhism, Taoism, and especially folklore. By analyzing ghost stories that represent the most typical case or expression of the complex relationship between Confucianism and folklore in the Vietnamese truyền $k \grave{y}$ genre, this article concludes that all the ontological crises of Confucianists that manifested in truyên $k \dot{y}$ derived from this tradition of folklore which created a minor discourse of a Confucian literatus who wrote on the periphery of official Confucianism. 


\section{Nguyen Thi Kim NGAN}

\section{Confucianism and Folklore in Vietnamese Fantasy Short Stories: The Case of Ghost Stories}

\section{Introduction: Truyền kỳ Genre and Vietnamese Confucianism}

With their geographical position at the "center of the center" in Southeast Asia, which has connected many important roads and seas and has created a brilliant agricultural civilization for 4000 years, the Vietnamese have created a folkloric tradition with a unique identity and systems of custom. According to the ancient history of the Comprehensive History of the Great Viet (Đại Việt Sử Ký Toàn Thư') (1479), compiled by Ngô Sỹ Liên, through more than 1000 years of Northern Domination and violent and bloody wars, from the tenth century onwards the Vietnamese built an independent feudal state. Since this important historic milestone, the feudal dynasties chose Chinese characters as the official script and officially opened the historical process of Vietnamese literature written in Han characters. In this cultural space, it is understandable that Vietnamese medieval literary genres, including the truyền kỳ genre, borrowed from the literature of China:

Truyền $k \dot{y}$ is defined as a genre of short stories that originated from China, which was conceived from traditional myths, fairy tales, legends of ancient time, and chronicles under Early Qin (221-206 BC), and inherited the traditional strange tales from the reign of Wei Jin (265-420) as well as the period of Western Han (265-316) and Eastern Han (317-420). For content, truyền kỳ borrowed stories from the folklore and explored the motifs, themes, and plots available from the folklore. For narrative art, it used unusual things and phi kỳ bất truyền (nonfantasy, not pass by tradition) as the creative method to describe the profound content issues related to social life. (Ngan 113)

Although originating in China and spreading to countries within the same text, including Vietnam, Japan, and Korea, Trân Ích Nguyên in Comparative Study of Tieu Dang Tan Thoai and Truyen ky man luc (2000) and Nguyễn Đăng Na in Vietnamese Narrative Prose in Medieval Times (2000) agree that when truyền kỳ was imported into each country, depending on the circumstances, they were transformed into a unique literary feature for each nation.

In Vietnam, from the second century AD onwards, Confucianism, Taoism, and Buddhism imported to Vietnam from China, simultaneously coexisted. Although Buddhism never completely lost the support and patronage of the feudal court from the tenth century onward, Confucianism was the chosen ideology and foundation for the operation of the imperial apparatus. Confucianism had never placed great emphasis on metaphysics or required people to have "the faith" or spiritual power redeemed as a conventional understanding of religion. Confucianism in China refers the tradition and theory of intellectuals and scholars. However, in reality, it meant more than the value of a group of people. According to John Berthrong and Evelyn Berthrong:

Confucianism, at various times and places, was a primordial religious sensibility and praxis; a philosophic exploration of the cosmos; an ethical system; an educational program; a complex of family and community rituals; dedication to government service; aesthetic criticism; philosophy of history; the debates of economic reformers; the intellectual background for poets and painters; and much more (1).

According to the Comprehensive History of the Great Viet, Confucianism was introduced into Vietnam around the first century BC (155). Although Confucianism appeared in Vietnam early, to the $L y$ dynasty (1009-1225), Confucianism began to compete successfully with the state religion at that time, Buddhism (Anh 262). This religion flourished in Vietnam in the feudal era in the Lê dynasty (1418-1527). This was the period when the Vietnamese state had an urgent need to organize and manage the country by a rigorous system. With the penetration and step-by-step control of the social life and political system due to Confucianism, Vietnamese society was clearly divided and formed new classes that existed beyond the old classes. The elite, occupying the monopoly power in society at that time, were Confucianists. Then historic documents noted that "the principles of Confucianism were filtered and Vietnamized, made into the ceremonial wedding and funeral and the specific behavior in the living. Despite being influenced by Confucianism, Buddhism, and Taoism, from family kinship to the village, the Vietnamese adopted Confucian ethics as a standard for communication anywhere" (Ước 353, my translation).

The authors of Vietnamese medieval fantasy short stories were all successful Confucians and officials for the court. However, unlike Chinese Confucians, most of the Vietnamese truyền $k \grave{y}$ writers came from wet rice farming villages, and they naturally grew along with traditional narratives and a plentiful system of indigenous beliefs. The most famous truyền kỳ writers, such as Lê Thánh Tông (1442-1497), Nguyễn Dữ (sixteenth century), and Đoàn Thị Điểm (1705-1749), studied the folklore's material, the knowledge 
of the uneducated, and the art of mountain and remote rural narrators. The stories that circulated throughout the generations provided typical prototypes, charismatic plot models, and special attractions. The authors accepted plot experiments from folklore and reproduced these stories into memorable short stories by complementing new experiences from their cultural environment.

Thus, with the characteristics of a typical polytheistic country, and with an innate metaphysical cosmology, there was a need to regularly return to the theological state to express a strong belief in the world. Vietnamese Confucian writers had fully enjoyed this unique folkloric background to create a distinct identity of truyền kỳ genres. Therefore, the birth and immediate development of the truyền $k \dot{y}$ genre in Vietnam, on the one hand, was strongly influenced by the worldview of Confucianism, a religion from China that had been adopted by the Vietnamese over the centuries. On the other hand, it was the product of the endogenous development of the ramifications of the national short story, which was ethnically associated with folk literature and historical prose. Easily found in history books such as Stories about Vietnamese Spiritual Realms (Việt Điện U Linh) of Lý Tế Xuyên in the thirteenth century, and the Hồng Đức Poem Collection of Lê Thánh Tông in the fourteenth century, there are historical events and traces related to famous folk tales, such as Từ Thức, Nam Xương Woman Tale, or the Vân Cát Goddess, before they were recreated into classic fantasy stories by Confucian writers.

However, the inheritance of elements from folklore in the short stories during the Middle Ages in Vietnam was the manifestation of a general genre evolution known worldwide in the transitional period, from oral literature to written literature. Generally, in the East and particularly in Vietnam, the recognition of folklore's role in the formation of literature writing is not controversial. However, beyond the obvious inheritance commonly found in the East, the relationship between folklore and Confucian ideology in the Vietnamese truyền kỳ genre proved to be very complicated.

At the time of its inception in the fourteenth century, as well as at the glorious top of this genre in the sixteenth century, truyền kỳ had never been accepted as an official genre. Those who were trained Confucianists believed that truyền $k \grave{y}$ stories placed an emphasis on folk narratives which had an inferior standing, belonging to Vietnam's cultural periphery, and which contained a metaphysical cosmology that Confucianism could not address or respond to."They argued that following Confucius' commandment in the Analects, Confucius did not talk about strange stories, violence, riots and civil commotion, or evil spirits. The metaphysical cosmology in traditional stories thus became a common blind spot for Confucianism. It was this subjective reason that Confucius passionately advised his followers to reject.

However, along with the unique characteristics of truyền ky's cultural roots, the reason that Confucian writers who wrote truyền $k \dot{y}$ actively borrowed and recreated the source of traditional stories also came from shocking historical events that occurred continuously in the history of Vietnam in the Middle Ages. From the sixteenth century onwards, several severe historical events took place in Vietnam, including the war of the Southern and Northern Dynasties (1533-1677) between the Lê dynasty and the Mạc dynasty, the war between the Trịnh Lords in the South and Nguyễn Lords in the North (1627-1672), and the insurrection of the Tây Son army (1771-1785) (Anh 36). In the context of continuous violent and bloody wars between feudal corporations to compete for dominion power, and on the decadent feudal court that was ruling with the increasing poverty of the people, Confucianism, with its theory of wealth, peace rules, and the monopoly religion in the previous periods, was strongly crippled. Deficiencies of Confucian philosophy related to the metaphysical world were exposed in competition with the non-Confucian religions that arose, such as Buddhism, Taoism, and especially folklore.

All the crises of the Confucianists manifested in the truyền ky and the continuation of the folklore tradition created a minor discourse among intellectual writers from the peripheral field of Confucianism. With this sociohistorical approach, through the famous truyên kỳ collection in The Excursive Notes on Weird Stories (Truyền kỳ mạn lục) of Nguyễn Dũ, The Draft Left from The Time of Thanh Tong King (Thánh Tông Di Thảo) of Lê Thánh Tông, Written Continuously from the Truyền kỳ Story (Truyền kỳ tân phả) of Đoàn Thị Điểm, and A Collection of Strange Stories of Lan Tri (Lan Trì Kiến Văn Lục) of Vũ Trinh, this study shows that with such a unique combination and deep contradiction, the birth and immediate development to the top of the Vietnamese truyền kỳ genre, on the one hand, was strongly influenced by the worldview of Confucianism, a religion from China that had been adopted by the Vietnamese over the centuries. On the other hand, it also was the product of the endogenous development of the ramifications of the national short story, which was ethnically associated with folk literature and historical prose.

\section{Confucian identity in the art space of truyền kỳ genre}

Having built from the notion of Confucius and turned into theory in the second century, this ideological movement, aimed initially at the family, then expanded into a national framework in Vietnam when it led to the integration of royalty, kingship, and theocracy into a system (Ước 124, Anh 15). 
Reflecting social, cultural, and political life in literature, the influence of Confucianism was prominent in truyền ky given that the social and ideological space of the stories were all arranged into a Confucian hierarchy. The feudal system was isomorphic to the divine order in the metaphysical world: the hierarchical rank of gods was a graphic representation of ranks in the real world. In that world, every event was organized and distributed according to its class positionality. All people and all things had their honor and position, destiny or fate. Each voice merged into a common melody, and every creature including ghosts, nine-tailed creatures, and bizarre creatures also played a role that was predetermined in God's equation and completely fulfilled the duties that God reserved. The space in truyền kỳ , consequently, created a sense of both mystery and unpredictability. On the other hand, to some extent, it turned out to be very orderly and was accordingly divided into two opposing poles.

For the vertical axis, the space was divided into classes and arranged in different positions for people based on the behavioral standards of the Confucian model. People who adhered to the behaviors of người quân tử [the man of honor] were always praised; after death, they received noble duties in the upper world. Story of Pham Tu Hu Visiting the Haven of Nguyễn Dữ (Truyện Phạm Tử Hư lên chơi thiên tào) described that on the occasion Pham Tư Hu' was taken to heaven by an old friend's spirit, he saw The White Pearl Palace and the Horoscope Palace which were the places where the emperor resided. The building named Door of Accumulate Virtues was the settlement of the upper spirituals: "Loving people all-around at the time of aliveness. All were praised with morality and great honor by God, consequently were here". In an official palace that has the title of the Thuận Thành door, and has millions of people who wore charming and elegant outfits "those are the noble living in filial piety or assisting poor people, living together through many difficult times without separation, The God praises for the kind-heartiness, so offer the upper palaces in which they will stay" (Nghĩa 254). Next is the Door of Confucian Spirits, where there were people who wore long dresses and gold belts, and thousands of people who used to be famous mandarins in Vietnamese history, such as Tô Hiến Thành in the Lý dynasty and Chu Văn An in the Trần dynasty; every 100 years they were born again, and they were honours by being reincarnated as civil and military court officials, and feudal intellectuals. This showed that the moral element of Confucian ideology deeply influenced the opposition between heaven and worldly things in the thoughts of the medieval writer. They believed that heaven was the place for a noble and eternal life; in contrast, the worldly was just for the sinful and transient. The "heavenly" space is often conceived of as a place where only the famous Confucian was enthroned after death and deification.

In contrast, hell was the world's negation, darkness, prison, death, and fear. The journey down to hell with cruel punishments would await those who behaved contrary to the morality of Confucianism. For example, this world had always included devils ready to take revenge on the person who burned the temple in Story of the Judge in Tan Vien Temple (Truyện chức phán sự đền Tản Viên). There were always punishments for those who broke Confucian moral standards, such as in The Evil Woman Story (Truyện mụ ác). In another story, the story of General Ly (Truyện Lý Tướng quân), General Lý died after being sent to hell with horrible punishments in Cứ $U$ [belonged to the hell] and the proclamation of the gods for his perdition in many lives. Prominent motifs were frequently used in these stories, such as (A671.2) horror scenes in hell, (F177.1) courts in other worlds, (F171.6) mysterious punishments in other worlds, or (E166) to be returned from the dead and granted another lifetime (Thompson 1958).

On the horizontal axis, the space of truyền kỳ stories was divided into religious centers connected with the secular periphery. The spiritual centers in Vietnamese culture were temples to worship those enclosed with their glorious feats of arms. They were famous in history, and their virtues had shined onto many generations. It was considered that unreal characters existed in the historical sense: they were supported by folk beliefs and the current dynasty, and gradually became true characters praised by the people. The dense appearance of god shrines in the Middle Ages was a unique feature of the Vietnamese cultural interface. After this phenomenon, there was a delicate combination of kingship, theocracy, and the patriarchy that emerged in the situation of the Middle Age's keen spirituality. Trân Nho Thin adds: "The feudal dynasties not only repressed internal violence revolts, struggled against external invasions, applied political theory and administered some methods to assure people, but also promoted religious power in their government. The emperors did not only sponsor the religion but also could be the head of religion" (141, my translation).

Religious centers occupied an essential and mysterious place where spirits and the dead had the opportunity to converse and transmit the messages of divine forces, including souls from the past or future, for posterity. Thus, truyền kỳ stories also made frequent visits to the sacred space, which mainly revolved around folklore motifs: (F163.2.1) temple in the otherworld, (F960.3.1) nature's lament at the temple's destruction, (J2162.1) burning the temple to attain notoriety, (N711.4.1) lovers meet at temple, (E755.4.2) or soul of the dead in a temple (Thompson 1958). In the story named The Two Gods of Filial Piety (Hai vị thần hiếu để), for instance, the main character inadvertently gets lost in another 
world in the sacred temple and meets his dead relatives who had become the guardian gods of the temple at the time, where he is informed about his destiny in the future. In another example, the religious centers were the settlements of ghosts and devils, in which someone could pay his or her life for breaking metaphysical rules. In the story of The Judge at Tan Vien Temple, Tứ Văn, the main character who burned the temple, nearly lost his life: "After he had burned the temple, he came home and was found uncomfortable, dizzy, stomach trembling and fever. During the fever, he saw a gentle and charming man who was in the headpiece coming, talked, was in clothes of the northern, called himself a recluse, and asked him to rebuild the temple as the former" (Nghĩa 238. my translation).

Meanwhile, folktales are seldom attached to specific epochs, and truyền kỳ stories concerned with established national identities are often written either about the era of the writer himself, or past dynasties. The united space around the religious centers was that of secular, peripheral life. It was the daily living environment of humans with clear and specific lands, historical milestones, dynasties, and real battles recorded in history. In fact, after the reign of Lê Thánh Tông, the great dynasty in history, the feudal dynasty went gradually into crisis. The aggressive war between the Mac (1527-1592) and Lê dynasties (1545-1592), and another war between the Trịnh Lords and Nguyễn Lords (1627-1672) caused severe political conflicts, and broke the stability and prosperity that the Lê dynasty had created for many years. All of the stormy historical events in this period were recorded by the Confucian literatus in truyền $k \dot{y}$, with details and events fitting with reality. It was the war that caused the painful tragedy of Ms. Vũ Nương: "The family union had not lasted so long, yet the State had war events with the war with Champa and forced the young to join the army. Although Mr. Truoong was blood-identified and not fully educated, his name was listed on the record of army duty; as a result, he was forced to participate in the army" (Nghĩa 288).

This social turmoil saw the increase of political conflicts between the old and new dynasties, and the fight against foreign powers, with humans suffering from interminable warfare:

In the Kiến Tân Date of Kỷ Mão year (the year of the Cat) (1399) belonged to Trần dynasty, there was a calamity of Trần Khát Chân, Lệ Nương was forced into the imperial palace ... until the end of the Hồ dynasty, the Ming General Trương Phụ classified the military to rob and invaded the capital city. Sinh heard that the Chinese army had to run away and predicted that Lệ Nương certainly followed. (Nghĩa 301)

In addition, the secular space of truyền ky stories also deeply depicted the living space of urban people through the ghost stories of generic men and charming women in which they mentioned pleasant sexual sympathy as a form of escaping from real life and breaking the rules of feudal behavior. The construction of sacred spaces in connection with the secular periphery strongly influenced the narrative structure of truyền $k \dot{y}$ stories. In this approach, the truyền $k \dot{y}$ writers always helped their readers unintentionally realize a brief glimpse of a model that existed mysteriously or metaphysically. This model fought against realism and reasoning through real historical events.

Due to the dominance of the Confucian vision, the space of truyền kỳ stories functioned in such a way that the medieval human and social worldviews supported one another within the framework of a system of unified thought. On the other hand, this religious sentiment, in coexistence with the Vietnamese polytheistic and spiritualist views, had contributed to the complex artistic conception of the writers. The literary space in the truyền kỳ genre, thus, was both a fully nihilist view and focused on the stormy life of reality. It was also the combination of mystical beliefs and existential opinions. All of these properties in the truyền kỳ genre were both the result of the rational thought of Confucianism and of a mysterious worldview and full metaphysical experience in folklore.

\section{Ghost stories as a representation of the conflicts between folklore and Confucianism in the truyền kỳ genre}

Confucianism from the beginning was a moral doctrine that was spread to other fields. This religion lacked a system of metaphysics, and metaphysics is also a problem that Confucian knowledge of truyên $k \dot{y}$ authors cannot meet. With an ideological system that binds people in many ways, it is clear that Confucian influence is not an advantage for the creation of artistic literature. The author of truyền $k \dot{y}$ must, therefore, borrow and offset this shortfall from non-Confucian sources, especially from folklore (Ngan 2021). This feature reveals a stylish dialogue in art, and an expression of the conflict between folklore and Confucianism.

The center of the metaphysical world formation in the medieval truyền kyे genre are the ghost stories. There are 29 stories about ghosts in the total of 95 truyền ky stories printed in General Collection of Vietnamese Novels Written in Han Characters (Tổng tập văn xuôi chữ Hán Việt Nam), which includes the collections of Nguyễn Dũ, Lê Thánh Tông, Đoàn Thị Điểm, and Vũ Trinh. The metaphysical world of 
ghost stories created different characteristics, and showed the efforts of Confucian writers receiving folk narratives in order to reconstruct the truyền kỳ genre.

Stories related to the ghost world in the truyên $k \dot{y}$ genre generally took place in two directions. The first was a living, accidental, or intentional visit to the world of ghosts, demons, and spirits. After that, the visitor underwent certain negotiations, struggles, or hardships to achieve the goal of returning to the mortal world from the world of the dead. Many familiar folklore motifs, therefore, appeared in these stories, such as (F81.1) the journey to the land of the dead to bring back a person from the dead, (F105) the dead oppose the return of the living from the land of the dead, (F93.1.1) the dead place a net across a river to prevent the living man from returning to earth, and (E141) resuscitation: ghosts deceived so that they cannot find way back to grave (Thompson 1958).

In the Devil Women Story (Mụ ác), the Hà character hears many calls to the door while asleep, and upon opening the door sees many white-eyed ghosts, who were forced to call him to the hell world by the village guardian. The story describes the character's near-death experience, until, awakening from his dream, he returns to the world, but with blood on his shirt. He suddenly exhibited wounds on his skin and harsh judgment of the gods for his future and family. Another series of stories along this trend, such as the story of Poetry Talk in Kim Thoa (Cuộc nói chuyện tho ở Kim Thoa), describes accidentally falling into the world of ghosts. The character Mao Tử Biên passes through strange places, where the grave of the famous female author Ngô Chi Lan is located. There, he witnesses an elegant literary conversation, composes poetry with the deceased, and listens to the messages of the ancients. The story ends when Mao Tứ Biên wakes up early the next day and realizes that he had slept beside the graves in the cemetery.

In the opposite direction, the deceased person's soul can reach the goal of penetrating the world of the living, and achieving a certain grace that had not ended in the world. These were the stories of devils whose souls could not be salvaged due to their entanglement in affairs in this world. Hence, there were stories about the vengeance of the ghosts with typical folklore motifs, such as (E200) the malevolent return from the dead, (E211.2.) a dead sweetheart appears to seduce every night, even after her beloved marries another woman, (E230) a return from the dead to inflict punishment, (E232.4) the ghost returns to slay enemies, and (E251.3.4) the ghost sucks people's breath (Thompson 1958). Typically, in the Karma of Đào (Nghiệp oan Đào Thị), the story depicted the floating fate of a famous singer named Hàn Than. After she died, she and her lover ghost, a monk named Vô Ky, reincarnated into the family of the chancellor, named Nguy Nhược Chân, to take revenge on a past debt and turn the family's magnificent castle into the abyss of the water monster. Motif E230 involves a return from the dead to inflict punishment (Thompson 1958), and is especially popular in stories about the journey of ghosts to real life.

Although the content is often quite short, a characteristic of truyền kyे, the stories of the ghost and afterlife were closely associated with sexuality, which was absent from mainstream medieval literature but strongly existed in the Vietnamese festivals, folk songs, and "yoni-linga" belief. Ghosts are thus often associated with illicit passions. The shadows of the women often hovered between the darkness and the light, e.g., "Bringing stars to come and wearing the moon to back" (Nghĩa 125), settling down by riverbanks or solitary bridges, seducing people, and waking up their instinctive aspirations. The journey of characters toward the ghost world in truyền kỳ symbolizes a charming but dangerous journey, and closely combines love and sexual desire.

The stories that refer to a sexual encounter with ghosts often follow the same trend: a person meets a beautiful girl, who invites him to stay the night, during which he enjoys an experience of romantic sex. In Story of Silk Cotton Tree (Truyện Cây gạo), the soul of Nhị Khanh takes Trình Trung Ngộ to the boat and flirts with him so that:

Thinking that the living is such a dreadfulness passing by. Letting by God naturally gives life to us, we search for delightedness pleasure constantly. If not making it come true, someday we die by chance even in the golden hell, we even wish to any sexual and pleasant romance consequently, it is impossible to achieve anymore. Now, daring you to throw the lighted into the darkness, to release the warmness dry germs, making leafs and flowers fall down, being received a little the spring day's fullness...and making love together. (Nghĩa 203)

The Story of Mysterious Meeting in Western Farm (Chuyện kỳ ngộ ở trại tây) also depicts the seduction and invocation of the spiritual flowers in the shape of beautiful girls: "two girls stood beside the ruined wall, laughed, and picked fresh fruits, plucked the beautiful flowers and threw them to Sinh. At occasionally, Sinh could not ignore away. Generally, they spent a fervent night together" (Nghĩa 215). When waking up in the morning or after a long time, the young student ordinarily finds that he slept over in the cemetery or a desolate house. Then, a wise and generous old man informs him that the 
person who talked with or had sex with him was the ghost of the object, animal, or the soul of a dead person.

The details of the sexual relationship between the ghost and men are repeated over and over, with two contrary tendencies. At one extreme, the story's describe the interaction between the woman ghost and a living man that finally brings about both physical and mental depletion was often seen as the death of the man. The Story of Silk Cotton Tree was written based on this pole. The character named Trinh Trung Ngộ meets the beautiful girl Nhị Khanh with her maid carrying the Hu violin (a musical instrument of China). Nhi Khanh decides to seduce him, and they enjoy a nightly sexual romance together. At a later time, Trinh Trung Ngộ follows his friends' advice to visit her home and unexpectedly sees a small coffin, which was carved with the words "Coffin of Nhi Khanh", and there was the picture of the girl holding a Hu violin. Despite recognizing that Nhi Khanh was only a ghost, Trinh Trung Ngộ found it impossible to stand against the seducement and attachment of the dark ghost; from then on, he was seriously ill. The wraith of Nhi Khanh "also often passed-by, sometimes stood by the riverbank to call, or sometimes came outside the window to whisper. Trung Ngộ frequently responded to her and wanted to follow her" (Nghĩa 206). Finally, he hugs her coffin to die. Both of them become devils residing in the old bombax tree, walking hand in hand every night, sometimes laughing and sometimes crying as well as scattering the seeds of disaster everywhere. In another story, the Karma of Đào (Nghiệp oan Đào Thị), a woman named Đào Thị lives on the Pháp Vân pagoda after a series of events in which she is a victim. Here, her karma becomes stronger when she continues to have an adulterous relation with the Vô Ky. monk. She dies in the process of giving birth, but her shadow of the ghost still returns in Vô Ky's dream and seductively invites him to another world to enjoy their love together. Soon after the death of Đào Thị, Vô Ky draws his last breath.

The blossoming of the image of women ghosts in the truyền kỳ genre perhaps resulted from their low-level position in the patriarchal family unit. They were women who passed away when they were too young, did not possess any family or children to worship, and stood outside of their ancestral worship system; therefore, they became wandering souls without anchors between the worlds, full of resentment. Returning by sexually seducing a man or seeking a woman ghost as a companion was officially a reflection of the desire to establish the position of women in a patriarchal Confucian society.

In another aspect, from sex to love, the association between men and women became a motivation for the women to resurrect again, for which their wandering souls had a chance to gain salvation. The Story of Mysterious Meeting in Western Farm is a unique work with consummate penmanship, in which Nguyễn Dữ lets the character named Hà Nhân become immersed in romantic love with Liễu Nhu Nương and Đào Hồng Nương in the space of the haunted garden. Being discouraged from an academic career and being passionate about sexual pleasures was the attitude that Hà Nhân selected, instead of dwelling on the classics and history. Even when his parents arranged a marriage for him, he still refused and returned to the capital city to enjoy love with the two lovers of flower souls. Upon discovering that they were not free souls, Hà Nhân wrote a tragic poem, and undertook a ritual meal and funeral oration to worship them. This detail in the story offers a reminder of the character Jia Baoyu, who composed the doleful funeral oration for the death of Qingwen, his trusted maidservant and confederate rose in $Y i$ Hong Yuan place, in Dream of the Red Chamber, one of China's Four Great Classical Novels written by Tsao Hsueh-Chin. These people, despite living in the abyss of constant obligations of morality and ethical behavior, as well as in a corrupt and depraved society, still thought and acted according to their hearts. Love was at that time portrayed as an entity that reconciled the difference between the living world and the dead world, and eradicated the boundaries between class and ideology. The deeply peaceful ending of the stories, moreover, made visible the implication that the connection between men and women as well as between a man and the natural world was always filled with the energy of love and passion.

With the sexual issue, the ghost stories revealed more clearly the deep conflicts between Confucianism and folklore in the truyền kỳ genre. While Confucianism was marked by sexual repression and the binding of political ideology, folklore always aimed to free people from all restraints. Confucianism was itself a complex ideology. That complexity indicated not only restricting the development of individuality, but also of informing universal moral principles and the psychology of antisacrilege and anti-rebellion. In addition, Confucianism also provided two modes of behavior for Confucian scholars: "dụng chi tắc hành xả chi tắc tàng" (being treasured talents, dedicated to serving the life, if not being treasured talents, chose the life of seclusion, they were frustrated but not to rebel). On the other hand, in the situation of choosing rebellion, the revolt was the behavior of society, in the art and literature, that rebellion was hidden in the behavior of love and sex pursuits. In other words, the journey for seeking love and sex meaningfully symbolized the social discontent or hostility that the writers could not directly claim. 
Especially by describing the sexual intercourse between man and ghost as a blamed problem, the authors point out that the surface of this tendency was in encouraging kindness and punishing badness, condemning sexual desire through the Confucian ideology of the Tống Dynasty: "Diệt nhân dục, tồn thiên lý" (having preservation to the natural order and eradication of sexual desires). Since then, the major voice of the story's ending was always the moral education to be derived from the lifestyle and behavior of the characters who represent taboos regarding political and sexual issues:

Being the devil from the ancient time despite not being a trouble disaster to people, the man of sexual desire always committed. Pure heart, it would be better to have less sexual desire. If the sexual desire is controlled, the heart will be peaceful and the goodwill comes, the devils cannot come to harass. The scholars who come to Trương An to study hard, even dare not wish to be any sexual desire but if try to control the sexual desire, it will be good. (Nghĩa 222)

What a such! Superstition is only harmful. Having followed it yet not to keep the rules, so how much the harmfulness is? Vô $K y$ is a lustful and sensual man, lies not only to people but also to the Buddha he worshiped. (Nghĩa 238)

With comments, it could be seen that the main purpose truyền kỳ authors wanted to convey in these stories included an educating philosophy: "Taking the righteousness to peace the rebellious, as well as spiritual strongness to keen, the loyalty to have self-protection and encouraging the kindness to punish the badness" (Nghĩa 314). In this way, the writers proved that they were members of the elite who carried out their moral and social responsibility as Confucian writers. On the other hand, from the standpoint of those who "sinh bất phùng thời" (living under unfavorable circumstances), they created ghost stories as a private space to explore their interests and emotions.

Although truyên $k \dot{y}$ 's authors, on the one hand, supported the Confucian stance to promote the model of "thánh nhân vong tình" (love, refusing superior men) and criticized people wallowing in "love", on the other hand, all of the comments of the stories' endings seem like just an excuse, as a form of camouflage to cover up their instinctual voices, to praise the right for sexual mutuality and the freedom of spirit for human beings. The cause of this phenomenon needs to be explained from the characteristics of the Vietnamese wet rice agricultural civilization.

From the beginning, Linga-ism (traditional fertility beliefs) that worshipped "linga-yoni" and sexual behavior had a close connection with agricultural beliefs, or intercourse between men and women on the grassland as a ritual of magical reproductivity. This traditional fertility also had a stimulatory effect, was a natural reminder, and allowed plants and animals to grow. Both sacred and mundane, and strongly existing in many sacred rituals of folk festivals, fertilized beliefs have created an "open" environment and the freedom of love between men and women under the patronage of gods in rural areas of Vietnam. According to Trần Ngọc Thêm, "The feudal Lê and Nguyễn dynasty that followed the Confucian view did not acknowledge this belief, they considered it as a profane custom and forced people to eradicate and change the contents of the festival" (238).

Most authors, however, lived closely with the rural people in the villages and grew up with a folk culture full of "yoni-linga" beliefs. Therefore, when the ambition and personal ideals serving the country and community were broken down due to violent political changes, and the rebellion and misery of people under war, scholars in such a crisis society were gradually becoming aware of their condition and their tragedy of being born in the wrong generation with many unreleased conflicts. They often instinctively reacted by hiding themselves in their full contradictory inner world with their contradictory passions. Moreover, in that world, the desires of love and sexuality between men and women became the wings and the way for Confucian scholars to seek their reason for living. The Confucian literatus, therefore, spread made efforts to depict all the good points, the beauty of love and sexual intercourse, by highlighting a world of people living in the ocean of passion and sex. The sexual "passion" of the individual for freedom of love between men and women, although not recognized in the comments at the end of truyền kỳ stories, was described as enlightened and romantic love. Simultaneously, this was the first time that the elements of love and sex had been introduced into medieval Vietnamese literature through dichotomous forms, which were both of negative and affirmative aspects. This perception of sexuality, which was considered the origin of sins, and also the top of purity, represented a new level of thought about the nature of life and death, and the contradictory conception of truyền ky stories between Confucian ideology and the Vietnamese folkloric foundation. Therefore, these stories occupied a marginal space in culture during the Middle Ages and continuously challenged and inspired the answer of "thoát Nho" (escaping from the effect of Confucianism) from the Vietnamese elite class.

\section{Conclusion}


The Truyền kỳ genre, from the earliest time of its inception, through to its development, and to its heyday, was just a minor discourse next to the orthodox discourses of the times. By selecting, collecting, and recreating folk narratives, truyền ky's authors expressed their opposition to the orthodox Confucian discourse and displayed an identity crisis. Although their loyalty to Confucianism was of paramount importance, they wrote with an interest in rebellious personal lives. Although influenced by Confucianism, they borrowed truyền kỳ plots from folklore to indirectly challenge Confucianism. Truyền $k \dot{y}$ stories were the incarnation of an unorthodox worldview, mental "rebelliousness", corrupt moral attitudes, and strongly expressed views on the ephemeral nature of life. By creating the truyền kỳ genre, to some extent, the authors of truyền kỳ lived in two worlds at the same time. The life of a welleducated, quintessential elite who followed the ceremonial rituals of the strict Confucian regulations and rituals, and the rebellious inner life with the values of folk-religious beliefs and freedom, which followed the mystical laws of nature and interacted with all the evil forces in the spiritual world. It also demonstrated the appearance of the collective reaction of writers to the trauma of war and the sudden change of various dynasties. The truyền kỳ genre written by Confucians, thus, was the place to concentratedly express the living suffering of humans and to expose the reality of a corrupted society at the highest level. With such a spirit, it is clear that this genre brought the germ of a humanistic revolution to the history of Vietnamese literature.

\section{Acknowledgements}

This research was funded by Vietnam National Foundation for Science and Technology Development (NAFOSTED) under grant number 602.05-2018.01.

\section{Works Cited}

Anh, Đào Duy. Lịch sử Việt Nam từ nguồn gốc đến thế kỷ XIX (Vietnamese History from the Origin to the Nineteenth Century). Social Science Publishing House, 2016.

Berthrong, John, and Evelyn Berthrong. Confucianism: A Short Introduction. Oxford. Oneworld Publications, 2004

Cadière, Léopold. Văn hóa, tín ngưỡng và thực hành tôn giáo người Việt (Vietnamese Culture, Beliefs and Religious practice). Translated by Do Trinh Hue. Thuan Hoa Publishing House, 2018.

Liên, Ngô Sỹ, Lê Văn Hưu, and Phan Phu Tiên. Đại Việt sử ký toàn thư (Comprehensive History of the Great Viet). 5th ed. Literature Publishing House, 2009.

$\mathrm{Na}$, Nguyễn Đăng. Văn xuôi tự sự Việt Nam thời trung đại (Vietnamese Narrative Prose in Medieval Times). Vietnamese Education Publishing House, 2000.

Ngan, Nguyen Thi Kim. "Folklore and Fantasy Short Stories in Medieval Literature of Vietnam: Otherworld Journeys." Asia - Pacific Social Science Review, Vol. 17, No. 1, 2017, pp. 112-120.

---. Nguyen Thi Thu Hang and Le Van Trung. "Identity of the Vietnamese Narrative Culture: Archetypal Journeys from Folk Narratives to Fantasy Short Stories. Humanities and Social Sciences Communications 8, $12,2021$.

https://www.nature.com/articles/s41599-020-00697-3

Nguyên, Trân Ích. Nghien cuu so sanh Tien dang tan thoai và Truyen ky man luc (Comparative Study of Tieu Dang Tan Thoai and Truyen ky man luc). Translated by Pham Tu Chau. Vietnam: Literature Publishing House, 2000.

Nghĩa, Trần, editor. Tổng tập tiểu thuyết chữ Hán Việt Nam (General Collection of Vietnamese Novels Written in Han Characters). 1st ed. The World Publishing House, 1997.

Quýnh, Trương Hữu, Đinh Xuân Lâm, and Lê Mậu Hãn. Đại Cương Lịch Sử Việt Nam (General History of Vietnam). 1st ed. Education Publishing House, 1998.

Thêm, Trần Ngọc. Cơ sở văn hóa Việt Nam (Vietnamese Cultural Identity). General Publishing House, 2006.

Thompson, Stith. Motif-Index of Folk-Literature: A Classification of Narrative Elements in Folktale, Ballads, Myths, Fables, Medieval, Romances, Exempla, and Local Legends (rev. ed.). Indiana University Press, 1958.

Thìn, Trần Nho, Văn học Việt Nam từ thế kỷ X đến hết thế kỷ XIX (Vietnamese Literature from the Tenth Century to the Nineteenth Century). Education Publishing House, 2012.

Tử, Khổng. Luận ngữ (Anlects). Literature Publishing House, 2013

Ước, Nguyễn. Đại cương triết học Đông Phương (General Eastern Philosophy). Knowledge Publishing House, 2009.

Xuyên, Lý Tế. Stories about Vietnamese Spiritual Realms. Translated by Lê Hữu Mục. Khai Tri Publishing House, 1961.

Author's profile: Nguyen Thi Kim Ngan is an Associate Professor at the Department of Literature and Linguistics, University of Education, Hue University, Vietnam. Her recent research has focused on Vietnamese folklore in social contexts, the history of folkloristics, and folk metaphysics. She is a member of the Executive Committee of the Vietnamese National Foundation for Science and Technology Development (NAFOSTED) and a member of the International Society For Folk Narrative Research (IFSNR). Email: <nganpedagogy@hueuni.edu.vn> 